\title{
PEMBELAJARAN KALKULUS BERBANTUAN MICROSOFT MATHEMATICS
}

\author{
Rina Oktaviyanthi, Yani Supriani \\ Universitas Serang Raya \\ Jl. Raya Serang-Cilegon Km 5, Taman Drangong, Serang, Banten 42162 \\ rinaokta1210@yahoo.com
}

\begin{abstract}
ABTSRAK
Penelitian ini menyajikan deskripsi investigasi penggunaan teknologi komputer dalam pembelajaran matematika, khususnya Microsoft Mathematics, dengan fokus pada pemahaman, sikap, dan pendapat mahasiswa selama proses pembelajaran. Studi ini memberikan bukti empiris tentang penggunaan program komputer Microsoft Mathematics, dalam mendukung eksplorasi pengetahuan dan kegiatan yang berkaitan dengan matematika tingkat lanjut, yaitu Kalkulus. Dua kelas dari mahasiswa tahun pertama di Universitas Serang Raya menjadi subjek studi ini. Kelompok kontrol mendapat perlakuan pembelajaran dengan metode konvensional dan kelompok eksperimen dengan menggunakan Microsoft Mathematics. Pendekatan penelitian ini adalah kkuantitatif dengan metode deskriptif analitis. Data penelitian diperoleh dengan mengumpulkan hasil pre tes dan post tes, mengisi kuisioner dan wawancara. Studi ini menemukan bahwa (1) penerapan Microsoft Mathematics memiliki pengaruh positif pada aspek teknologi pendidikan dalam memperkaya belajar matematika dan meningkatkan motivasi mahasiswa untuk lebih terlibat dalam kegiatan pembelajaran di kelas, dan (2) mahasiswa dengan pembelajaran berbantuan Microsoft Mathematics memiliki perolehan nilai yang lebih tinggi dan memiliki efek positif pada kepercayaan diri mahasiswa dalam belajar Kalkulus.
\end{abstract}

Kata kunci : kalkulus, microsoft mathematics, motivasi siswa, pendidikan matematika, teknologi pendidikan

\begin{abstract}
This research presents an investigative description the use of technology computer in learning mathematics, in this study is Calculus, with a focus on students' understanding, attitudes, and their opinions during learning process. It provided empirical evidence on the use of a program called Microsoft Mathematics in supporting knowledge exploration and learning activities related to one of the important subjects in advanced mathematics, Calculus. Two classes of the students from the first year student in Universitas Serang Raya were participated in the study. Control group was taught by using conventional teaching method, whereas experimental group was taught by using Microsoft Mathematics software. The research approach is a quantitative with a descriptive analytical method. The research data was obtained by collecting the results of the pre-test and posttest, filling the questionnaires, and interviewing the research subject. This study found that (1) applying Microsoft Mathematics has the positive influence of educational technology in enriching students' mathematics learning and increasing students' motivation to get more involved in classroom learning activities, (2) students who taught by using Microsoft Mathematics had higher achievement and has a positive effect on students' confidence of mathematics.
\end{abstract}

Keywords : calculus, educational technology, mathematics education, microsoft mathematics, students' motivation

\section{Pendahuluan}

Selama beberapa dekade terakhir, teknologi telah menjadi alat yang sangat penting dalam kehidupan sehari-hari. Komputer telah menjadi alat yang umum untuk komunikasi, pengolahan teks, dan 
banyak kegiatan lainnya, termasuk berbagai bentuk media, audio, grafis, video, dan virtual reality. Penggunaan komputer dan teknologi sehari-hari tidak hanya untuk hiburan dan komunikasi, melainkan juga pendidikan. Banyak lembaga pendidikan yang telah mempertimbangkan potensi teknologi dan berupaya mengembangkan standar pendidikan berbasis teknologi [1]. Aplikasi teknologi pada pendidikan dapat berupa pemanfaatan proses dan produk teknologi informasi dan komunikasi untuk memecahkan masalah-masalah pendidikan dan pembelajaran [2]. Teknologi pendidikan hadir dengan harapan dapat menyederhanakan perspektif suatu materi sehingga memudahkan peserta didik dalam mengerti dan memahami. Selain itu teknologi pendidikan tercipta untuk mendukung instruksi pengajaran yang berbeda, kecerdasan peserta didik yang beragam, dan pembelajaran eksplorasi [3].

Pembelajaran Matematika berkaitan erat dengan visualisasi dan representasi dari objek dan prosedur matematika. Dalam kaitannya dengan pembelajaran Matematika, teknologi dipandang sebagai alat dan komponen penting untuk mendukung visualisasi dan media interaktif [4], sehingga dapat membantu representasi, bernalar, mengkonstruksi perhitungan, mengeksplorasi dan memecahkan masalah. NCTM [5] menegaskan bahwa, "technology is essential in teaching and learning mathematics; it influences the mathematics that is taught and enhances students' learning. Teachers' attitudes play an important role in using technology in teaching and learning mathematics."

Pendidikan tidak lagi menekankan pada menghafal fakta-fakta dan gambar, melainkan tentang belajar menemukan suatu informasi dan yang lebih utama adalah bagaimana dan di mana informasi yang telah ditemukan itu dapat diaplikasikan. Peserta didik, dalam hal ini mahasiswa, harus aktif membangun pemahaman mereka sendiri dan bukan hanya menyerap dari apa yang orang lain sampaikan pada mereka [6]. Proses pembelajaran tradisional mendasarkan pada transfer pengetahuan secara langsung dari guru kepada siswa dan menerapkan pedagogi dimana peserta didik berperan sebagai penerima pasif pengetahuan. Hal tersebut yang menyebabkan konten materi yang disajikan di kelas terputus dari konteks dunia nyata, dan tentu saja memiliki dampak negatif pada proses pembelajaran, khususnya mempengaruhi motivasi peserta didik [7]. Penekanan penting lain yang diperlukan pada proses pembelajaran yaitu kebermaknaan bagi siswa. Menurut TIME (Technology Integrated in Meaningful Learning Experiences) kebermaknaan berpengaruh pada pengalaman belajar yang berarti harus menciptakan kesempatan untuk mencapai pemahaman yang mendalam tentang ide-ide kompleks dan memungkinkan peserta didik bekerja 
dengan masalah yang kompleks dan relevan dengan kehidupan mereka [8].

Penggunaan teknologi dalam pendidikan dapat meningkatkan pembelajaran bermakna lebih baik daripada pembelajaran tradisional. Dengan teknologi, peserta didik dapat terlibat lebih luas menghubungkan dunia sekolah dengan dunia nyata, memberikan display dinamis terkait beberapa representasi, model interaktif dan simulasi dari suatu materi belajar [9]. Dengan cara mengintegrasikan teknologi ke dalam proses pengajaran dan pembelajaran, diharapkan dapat meningkatkan kemampuan peserta didik dalam memahami ide-ide kompleks dan mampu mengonstruksi pemecahan masalah. Ada banyak penelitian yang telah memokuskan pada integrasi penggunaan teknologi dalam pendidikan dari berbagai perspektif. Sebagaimana yang dicatat oleh Churchill (2005), "technology amplifies our intellectual and physical capacity" [10], dan dalam konteks ini teknologi dapat menjadi peran penting dalam mendukung pembelajaran yang lebih kompleks.

Salah satu cara mengintegrasikan teknologi ke dalam pendidikan adalah dengan menggunakan komputer melalui instruksi multimedia untuk menyajikan dan mengomunikasikan materi pembelajaran. Instruksi multimedia adalah presentasi yang melibatkan katakata dan gambar yang dimaksudkan untuk mendorong pembelajaran [11]. Dengan cara ini, informasi dapat diproses melalui kedua saluran verbal dan nonverbal, sehingga peserta didik memiliki kesempatan untuk mengoptimalkan kognitif untuk mengambil informasi yang disajikan. Hal tersebut dapat dikaitkan dengan the dual coding theory yang dikembangkan Paivio (2006) yang menekankan konkretisasi pengetahuan melalui citra dan gambar [12]. Sebuah aspek penting dari instruksi multimedia adalah prinsip multimedia. Sehubungan dengan prinsip ini, Mayer (2001) menyatakan, "people learn better from words and pictures than from words alone. When words and pictures are both presented, learners have the opportunity to construct verbal and visual mental models and to build connections between them" [13].

Kalkulus adalah cabang ilmu Matematika yang mencakup limit, turunan, integral, dan deret takterhingga. Kalkulus yang memiliki aplikasi luas dalam bidang sains dan teknik, digunakan untuk membantu memecahkan masalah kompleks yang tidak cukup diselesaikan dengan teknik aljabar elementer. Berdasarkan hasil pengalaman penulis dalam proses perkuliahan pada mahasiswa tingkat pertama Fakultas Teknologi Informasi Universitas Serang Raya, diketahui kelemahan sebagian besar mahasiswa yaitu hanya mampu melakukan perhitungan sederhana. Permasalahan ini merupakan tugas dan tantangan bagi pengajar untuk mencari alternatif solusi agar pembelajaran Kalkulus tidak hanya dapat menarik minat dan memotivasi mahasiswa, tetapi lebih jauhnya dapat memberikan 
kesempatan pada mahasiswa untuk mengembangkan kemampuan dalam hal pemahaman, penalaran, dan pemecahan masalah. Pembelajaran dengan media komputer dapat digunakan sebagai solusi untuk permasalahan tersebut. Beberapa program komputer dapat digunakan sebagai media pembelajaran yang interaktif dan dinamis. Media pembelajaran yang interaktif dan diinamis yaitu media tersebut dapat digunakan secara mandiri maupun kelompok serta media tersebut mampu memberikan pemahaman kepada penggunanya atas permasalahan Matematika simbolik yang beraneka ragam [13].

Software Microsoft Mathematics adalah perangkat lunak yang memiliki sistem komputasi simbolik dan bekerja berdasarkan model-model matematika (dalam bentuk simbol atau ekspresi atau persamaan Matematika). Microsoft Mathematics sebagai software komputasi Matematika sangat cocok dimanfaatkan dalam membantu menyelesaikan permasalahan Aljabar Linier, Statistika, Kalkulus, Trigonometri, dan sebagainya. Atas dasar hal tersebut, muncul tema penelitian ini, yang bertujuan untuk menyelidiki peran dari program komputer, dalam hal ini Software Microsoft Mathematics pada proses belajar mengajar Kalkulus.

\section{Kajian Literatur}

Salah satu tujuan utama dalam pendidikan Matematika adalah untuk memastikan keberhasilan semua peserta didik dalam memahami materi Matematika. Matematika dianggap sebagai salah satu mata pelajaran/ kuliah yang paling menantang dan bermasalah dalam aspek pendidikan. Tetapi pada saat yang sama, Matematika merupakan kajian yang paling penting dari ilmu pengetahuan, mengingat Matematika sebagai pengetahuan yang banyak digunakan dalam kehidupan sehari-hari dan banyak diaplikasikan pada bidang ilmu lain. Matematika adalah alat dasar dalam menganalisis konsep-konsep setiap bidang dalam aspek kehidupan manusia [14]. Untuk alasan tersebut, pengajar harus fokus pada pengembangan pemahaman peserta didik tentang konsep-konsep Matematika dan perlu menyediakan sebuah lingkungan pendidikan yang berkualitas. Banyak peserta didik merasa sulit untuk terlibat dengan konsep-konsep Matematika. Untuk mendekati kesulitan yang dihadapi peserta didik, gambaran kegiatan Matematika dan proses melakukan. Sebuah kunci yang utama untuk memahami Matematika adalah penggunaan visualisasi dan representasi dalam proses belajar mengajar. Duval (dalam Curri, 2012) menyatakan, "there is no understanding of mathematics without visualization" [15]. Visualisasi dimaksudkan untuk menjadi sarana konkret yang memungkinkan peserta didik mengeksplorasi konsep-konsep Matematika.

Teknologi berguna untuk membantu peserta didik melihat Matematika tidak hanya sebagai satu set prosedur, tetapi 
lebih sebagai penalaran, mengeksplorasi, memecahkan masalah dan menghasilkan informasi baru. Selanjutnya, hal tersebut membantu mereka untuk lebih memvisualisasikan konsep-konsep Matematika tertentu. Penelitian telah mengungkapkan bahwa kegiatan yang mendukung visualisasi dapat meningkatkan pembelajaran Matematika [16]. Ashbum dan Floden (2006) menekankan pentingnya penggunaan teknologi dalam pembelajaran Matematika yaitu untuk membangun representasi grafis dan simbolis ekspresi Matematika sehingga dapat membantu peserta didik dalam membuat tujuan pemahaman [17].

Pendekatan teknologi melibatkan tindakan dan persepsi serta menghasilkan pembelajaran berbasis doing, touching, moving, dan seeing [18]. Dengan menggunakan instruksi multimedia, peserta didik dapat mengomunikasikan informasi, melibatkan lebih dari satu model presentasi, mengingat cara suatu materi dapat diwakili (berupa kata-kata atau gambar). Instruksi multimedia merupakan jalan bagi peserta didik untuk merepresentasikan objek Matematika yang abstrak. Penelitian menunjukkan bahwa menggunakan alat bantu representasi dalam proses belajar mengajar dapat mendukung pengembangan pemahaman Matematika peserta didik [19]. Mampu menghubungkan representasi matematis yang berbeda atau menghasilkan representasi baru dari objek yang sama, telah terbukti menjadi indikator kuat dalam upaya meningkatkan pengetahuan dan kemampuan pemahaman peserta didik.

Ada banyak peneliti yang menyimpulkan bahwa teknologi interaktif terutama alat visualisasi menjadi media yang efektif untuk melibatkan peserta didik dalam pembelajaran dan menciptakan suasana belajar yang bermakna [20]. Hal ini membuat visualisasi interaktif merupakan aspek penting untuk proses pembelajaran. Menghubungkan beberapa visualisasi berbeda dapat memberikan manfaat perkembangan kognitif yang berbeda pula. Teknologi yang digunakan untuk tujuan pendidikan perlu dilengkapi dengan animasi yang dinamis dan fleksibel sehingga peserta didik dapat membangun pemahaman dengan cara yang lebih baik. Hogstad \& Brekke (2010) menegaskan, "students need to see things moving to understand and to process information" [21].

Kalkulus merupakan bagian dari ilmu Matematika. Kalkulus memainkan bagian penting dalam kurikulum mahasiswa di universitas pada hampir semua disiplin ilmu, seperti teknik, ilmu pengetahuan, bisnis, ekonomi, ilmu komputer dan sistem informasi. Konsep-konsep dalam Kalkulus tersusun secara sistematis, logis, dan hirarkis dari yang paling sederhana menuju yang paling kompleks. Dengan kata lain, pemahaman dan penguasaan suatu konsep merupakan prasyarat untuk dapat menguasai konsep selanjutnya. Oleh karena itu, secara otomatis bahwa penguasaan Kalkulus 
merupakan hal penting dalam pembelajaran Kalkullus. Namun banyak yang menjadikan Kalkulus sebagai halangan dalam proses perkuliahan. Kalkulus sebagai bagian ilmu Matematika memiliki objek abstrak yang kebanyakan mahasiswa tidak mampu membayangkan objek tersebut.

Microsoft Mathematics merupakan perangkat lunak buatan Microsoft Corporation. Software ini memberikan kemudahan penggunanya dalam melakukan komputasi Matematika. Penulisan, perhitungan, dan manipulasi ekspresi matematis maupun visualisasi grafik 2D, 3D, dan animasi dapat dilakukan dengan instruksi yang mudah serta menampilkan langkah solusi dari suatu masalah sebagaimana yang diperoleh apabila dikerjakan secara manual. Misalnya diketahui fungsi $f(x)=x^{2}-3 x+4$ dan akan dicari turunan pertama dari $f(x)$ dan plot grafik 2D dan 3D. Penyelesaian dengan Microsoft Mathematics dapat dilakukan sebagai berikut:

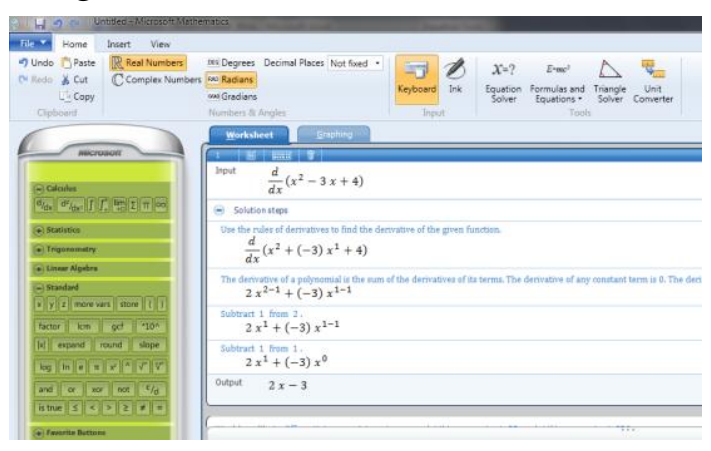

Gambar 2.1. Tutor Metode

Pendiferensialan dalam Microsoft

Mathematics

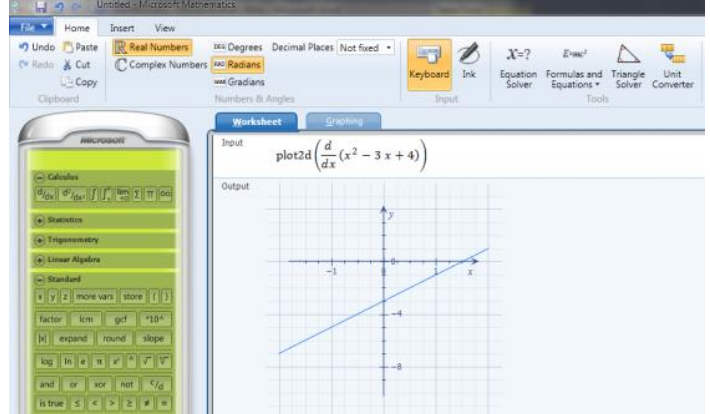

Gambar 2.2 Plot Grafik dalam 2D

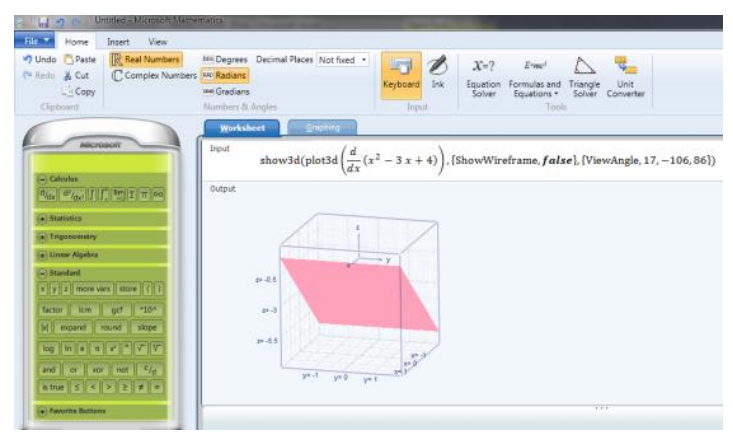

Gambar 2.3 Plot Grafik dalam 3D

\section{Metode Penelitian}

Tujuan utama penelitian ini adalah menyelidiki peran program komputer, Microsoft Mathematics dalam pengajaran dan pembelajaran Kalkulus pada mahasiswa tingkat pertama di lingkungan Fakultas Teknologi Informasi Universitas Serang Raya. Untuk mencapai tujuan ini, penulis menggunakan pendekatan kuantitatif, yaitu pendekatan yang memungkinkan dilaksanakan pencatatan dan penganalisaan data hasil penelitian secara eksak. Sementara metode penelitian yang digunakan adalah metode deskriptif analitis. Metode deskriptif berarti memberikan gambaran menurut apa adanya tentang hubungan keterpaduan, fungsional maupun konsekuensional antara variabel-variabel penelitian terkait. Sedangkan secara analitis berarti memberikan penyimpulanpenyimpulan menggunakan studi komparasi maupun studi korelasional. 
Populasi dalam penelitian ini adalah seluruh mahasiswa tingkat pertama jurusan Sistem Komputer pada Fakultas Teknologi Informasi Universitas Serang Raya. Sampel penelitian dipilih secara acak terdiri dari 22 mahasiswa.

Prosedur penelitian dimulai dengan menentukan kelas eksperimen dan kelas kontrol. Kelas A1 digunakan sebagai kelas eksperimen dengan 11 subjek penelitian dipilih secara random dan mendapat pengajaran Kalkulus berbantuan Microsoft Mathematics. Kelas A2 digunakan sebagai kelas kontrol dengan 11 subjek peneltian yang dipilih secara random dan mendapat pengajaran Kalkulus secara konvensional. Instrumen yang digunakan untuk pengumpulan data berupa tes (pre test dan post test), angket/ kuisioner, dan wawancara. Pre test diformulasikan sesuai dengan pengetahuan mahasiswa sebelumnya dan post test berisi pengetahuan yang diajarkan selama pembelajaran. Kuisioner yang digunakan dalam penelitian ini diambil dari artikel yang ditulis oleh Fogarty, Cretchley, Harman, Ellerton dan Konki (2001) [22]. Dalam penelitian dijelaskan bahwa kuisioner tersebut divalidasi dan digunakan untuk mengukur kepercayaan pada Matematika (Kalkulus), kepercayaan pada program komputer dan sikap terhadap penggunaan teknologi untuk belajar Matematika (Kalkulus). Wawancara dilakukan pada akhir pembelajaran dan menitikberatkan pada persepsi mahasiswa terhadap utilitas dan kegunaan dari program komputer selama pembelajaran berlangsung.
Setelah melakukan uji validitas instrumen, dan telah diperoleh data yang sesuai, maka dilakukan analisis data. Analisis data dilakukan dengan langkahlangkah sebagai berikut:

1. Verifikasi data. Langkah ini dilakukan untuk memeriksa kelengkapan pengisian yang dilakukan oleh mahasiswa sehingga data yang terkumpul memadai untuk pengolahan lebih lanjut. Hasil verifikasi pada data yang terkumpul dalam penelitian ini menunjukkan bahwa lembar jawaban mahasiswa semuanya memenuhi syarat.

2. Pemberian skor. Untuk instrumen tes mengikuti panduan pemberian skor Bryman (2008) [23]. Hasil tes dikalkulasi dalam persentase, dengan rincian sebagai berikut:

Tabel 3.1 Skor Penilaian Bryman

\begin{tabular}{ll}
\hline Excellent & $>\mathbf{8 5 \%}$ \\
\hline Very good & $70-85 \%$ \\
Acceptable & $60-69 \%$ \\
Barely acceptable & $50-59 \%$ \\
Not acceptable & $<50 \%$ \\
\hline
\end{tabular}

Sementara untuk instrumen angket/ kuisioner mengikuti panduan Likert Scale.

3. Pengelompokkan data. Data yang diperoleh akan dibagi ke dalam kategori-kategori tertentu sesuai dengan variabel-variabel yang terkait penelitian ini.

4. Persentase jawaban. Langkah ini dilakukan untuk melihat kecenderungan pilihan jawaban pada angket/ kuisioner yang diisi mahasiswa (responden). 
5. Analisis Statistik menggunakan program SPSS 12.00. Hasil yang diperoleh dengan program ini kemudian diterjemahkan sesuai dengan buku sumber yang dijadikan rujukan [24].

\section{Hasil dan Pembahasan}

\section{Klasifikasi Subjek Penelitian}

Klasifikasi karakteristik dari subjek penelitian diperlihatkan pada Tabel 4.1. Hasil pada tabel tersebut menggambarkan bahwa mayoritas kedua kelas penelitian (eksperimen dan kontrol) adalah laki-laki di usia 17-19 tahun (kelas eksperimen: 63.64\%, 81.82\%; kelas kontrol: 72.73\%, $90.91 \%)$.

Tabel 4.1 Klasifikasi Karakteristik dari 22 Subjek Penelitian Kelas Eksperimen dan Kelas Kontrol

\begin{tabular}{cccc}
\hline \multicolumn{2}{c}{ Klasifikasi Informasi } & \% \\
Kelas & Gender & Laki-laki & 63.64 \\
Eksperimen & & Perempuan & 36.36 \\
& \multirow{n}{*}{ Usia } & $17-19$ & 81.82 \\
Kelas & \multirow{2}{*}{ Gender } & Laki-laki & 72.73 \\
Kontrol & & Perempuan & 27.27 \\
& \multirow{nyy}{*}{ Usia } & $17-19$ & 90.91 \\
& & $20-22$ & 9.09 \\
\hline
\end{tabular}

\section{Deskripsi Kecakapan Siswa dalam Teknologi}

Tabel 4.2 berikut mengilustrasikan level kemampuan subjek penelitian sebagai pengguna teknologi yang berhubungan dengan pendidikan. Hasil menunjukkan bahwa sebagian besar subjek penelitian berada pada tingkat 'average' dalam penggunaan komputer yang berhubungan dengan teknologi pendidikan $(29.17 \%)$.

Tabel 4.2 Level Penggunaan Teknologi dari 22 Subjek Penelitian Kelas Eksperimen dan Kelas Kontrol

\begin{tabular}{lc}
\hline \multicolumn{1}{c}{ Students' Proficiency } & $\%$ \\
\hline Unfamiliar & 0 \\
I have no experience with computer technologies & 9.58 \\
$\begin{array}{l}\text { Newcomer } \\
\text { I have attempted to use computer technologies, but I still require help on a regular basis }\end{array}$ & \\
Beginner & 16.67 \\
I am able to perform basic functions in a limited number of computer applications & 29.17 \\
Average & \\
I demonstrate a general competency in a number of computer technologies & 20 \\
Advanced & \\
I have acquired the ability to completely use a broad spectrum of computer technologies & 24.58 \\
\hline $\begin{array}{l}\text { Expert } \\
\text { I am extremely proficient in using a wide variety of computer technologies }\end{array}$ & \\
\hline
\end{tabular}

Tabel 4.3 di bawah ini menjelaskan tentang tahapan siswa berhubungan dengan kegiatan pembelajaran yang mengintegrasikan teknologi dalam pendidikan. Dari hasil penelusuran angket diperoleh bahwa sebagian besar subjek berada pada tahapan 'learning' yaitu subjek sedang berusaha belajar matematika dengan memanfaatkan teknologi komputer meskipun memulai dari tahap dasar. Fakta tersebut memberikan hasil positif dalam pengembangan pembelajaran menggunakan komputer dan lebih jauhnya pemanfaatan teknologi pendidikan di dalam kelas. 
Tabel 4.3 Tahapan Subjek Penelitian Terkait dengan Aktivitas Pembelajaran yang Mengintegrasikan Teknologi Pendidikan

\begin{tabular}{lc}
\hline \multicolumn{1}{c}{ Students' Stage } & $\%$ \\
Awareness & 7.5 \\
I am aware that technology exists, but have not used it - perhaps I'm even avoiding it. & \\
Learning I am anxious about the prospect of using computers & 25.83 \\
I am currently trying to learn the basics. I am sometimes frustrated using computers \\
and I lack confidence when using them
\end{tabular}

\section{Eksperimen Pembelajaran dengan Microsoft Mathematics}

Penelitian ini bekerja pada metode desain eksperimen yang berhubungan dengan tujuan, skema rencana untuk mewujudkan tujuan, pengumpulan dan analisis data (MacDonald, 2008) [25]. Penelitian ini mengorganisasikan aktivitas dari penggunaan Microsoft
Mathematics dalam pembelajaran berdasarkan pada tiga tujuan penggunaan media dalam proses belajar mengajar (Wilson, 2008) [26]. Detil aktifitas penggunaan Microsoft Mathematics dalam pembelajaran dijabarkan pada tabel berikut dengan pengembangan secukupnya.

Tabel 4.4 Aktifitas Penggunaan Microsoft Mathematics

\begin{tabular}{|c|c|c|c|}
\hline \multicolumn{2}{|c|}{$\begin{array}{l}\text { Purpose of using } \\
\text { the tool }\end{array}$} & \multirow{2}{*}{$\begin{array}{l}\text { Description } \\
\text { Students used Microsoft Mathematics to try different } \\
\text { approaches to solve a given Calculus problem. For } \\
\text { example, in solving problems students may start } \\
\text { looking for a solution with the graphical, numerical, } \\
\text { or algebraic approach. }\end{array}$} & Pedagogical benefits \\
\hline $\begin{array}{l}\text { Promot } \\
\text { ing } \\
\text { drill } \\
\text { and } \\
\text { practic }\end{array}$ & $\begin{array}{l}\text { As a } \\
\text { problem } \\
\text { solving }\end{array}$ & & $\begin{array}{ll} & \text { Reduction time } \\
\text { required to practice } \\
\text { basic skills } \\
\text { - } \begin{array}{l}\text { All students involved in } \\
\text { teaching and learning }\end{array}\end{array}$ \\
\hline e & $\begin{array}{l}\text { As a } \\
\text { calculati } \\
\text { on }\end{array}$ & $\begin{array}{l}\text { Students applied Microsoft Mathematics to determine } \\
\text { of the values of the function or to estimate Calculus } \\
\text { multiple expressions. }\end{array}$ & \\
\hline \multirow[t]{2}{*}{$\begin{array}{l}\text { Variati } \\
\text { on of } \\
\text { parame } \\
\text { ters }\end{array}$} & $\begin{array}{l}\text { As a } \\
\text { visualiza } \\
\text { tion }\end{array}$ & $\begin{array}{l}\text { Students utilized Microsoft Mathematics to facilitate } \\
\text { the better visualization of a function, the concept that } \\
\text { is taught or problem situation. For example, students } \\
\text { changing parameters of the Calculus function and } \\
\text { looking at the changes in the graphical characteristics. }\end{array}$ & \multirow{2}{*}{$\begin{array}{l}\text { Direct feedback is } \\
\text { helpful to make the } \\
\text { relation between the } \\
\text { parameters in Calculus } \\
\text { functions and assist to } \\
\text { construct a variable } \\
\text { effect the graphical } \\
\text { representation }\end{array}$} \\
\hline & $\begin{array}{l}\text { As a } \\
\text { graphing }\end{array}$ & $\begin{array}{l}\text { Students used Microsoft Mathematics to graph } \\
\text { function and to solve problems related to area under a } \\
\text { curve or area of intersection of the two curves. }\end{array}$ & \\
\hline
\end{tabular}




\begin{tabular}{llll}
\hline $\begin{array}{l}\text { Concep } \\
\text { tual } \\
\text { underst } \\
\text { anding }\end{array}$ & $\begin{array}{l}\text { As an } \\
\text { explorat } \\
\text { ory }\end{array}$ & $\begin{array}{l}\text { Microsoft Mathematics applied to investigate and } \\
\text { recognize concepts of integration. For illustration, } \\
\text { students explored and presented integration of one or } \\
\text { more function using Microsoft Mathematics in the } \\
\text { algebraic and graphical representation. }\end{array}$ & $\begin{array}{l}\text { Emphasis on } \\
\text { recognizing of learning } \\
\text { the algorithm for } \\
\text { solving function } \\
\text { equations }\end{array}$ \\
& $\begin{array}{l}\text { As a } \\
\text { confirma } \\
\text { tory }\end{array}$ & $\begin{array}{l}\text { Students applied Microsoft Mathematics to validate } \\
\text { their answers in problem solving tasks. }\end{array}$ & \\
\hline
\end{tabular}

Aksesbilitas Microsoft Mathematics merekomendasikan siswa tidak hanya dalam penemuan konsep materi Kalkulus, tetapi juga dalam mengkomunikasikan konsep-konsep materi Kalkulus secara matematis. Dengan menggunakan Microsoft Mathemmatics siswa mampu mempresentasikan solusi dan memberikan umpan balik kepada pengajar selama pembelajaran.

\section{Hasil Pre dan Post Test}

Tabel 4.5 dan 4.6 merupakan hasil pre test dan post test serta rata-rata hasil test dari kelas eksperimen dan kelas kontrol.

Tabel 4.5 Pre test dan post test kelas eksperimen

\begin{tabular}{rcrrr}
\hline No & $\begin{array}{c}\text { Kelas } \\
\text { Eksperimen }\end{array}$ & \multicolumn{1}{c}{$\begin{array}{c}\text { Pre } \\
\text { test }\end{array}$} & $\begin{array}{c}\text { Post } \\
\text { test }\end{array}$ & \multicolumn{1}{c}{$\begin{array}{c}\text { Difference } \\
\text { of result }\end{array}$} \\
\hline $\mathbf{1}$ & S1 & 90 & 95 & 5 \\
$\mathbf{2}$ & S2 & 87.5 & 90 & 2.5 \\
$\mathbf{3}$ & S3 & 82.5 & 90 & 7.5 \\
$\mathbf{4}$ & S4 & 66 & 73 & 7 \\
$\mathbf{5}$ & S5 & 61 & 70 & 9 \\
$\mathbf{6}$ & S6 & 68.5 & 75 & 6.5 \\
$\mathbf{7}$ & S7 & 75 & 70 & -5 \\
$\mathbf{8}$ & S8 & 90 & 90 & 0 \\
$\mathbf{9}$ & S9 & 49.5 & 63 & 13.5 \\
$\mathbf{1 0}$ & S10 & 77.5 & 75 & -2.5 \\
$\mathbf{1 1}$ & S11 & 70 & 83 & 13 \\
& Mean & 74.32 & 79.45 & 5.14 \\
\hline
\end{tabular}

Tabel 4.6 Pre test dan post test kelas kontrol

\begin{tabular}{llrrr}
\hline No & $\begin{array}{l}\text { Kelas } \\
\text { Kontrol }\end{array}$ & $\begin{array}{l}\text { Pre } \\
\text { test }\end{array}$ & $\begin{array}{l}\text { Post } \\
\text { test }\end{array}$ & $\begin{array}{l}\text { Difference } \\
\text { of result }\end{array}$ \\
\hline $\mathbf{1}$ & $\mathrm{S} 12$ & 73 & 58 & -15 \\
$\mathbf{2}$ & $\mathrm{S} 13$ & 82 & 78 & -4 \\
\hline
\end{tabular}

Pengembangan ... (Laela Sagita)

\begin{tabular}{lrrrr}
\hline $\mathbf{3}$ & S14 & 64.5 & 75 & 10.5 \\
$\mathbf{4}$ & S15 & 76.5 & 75 & -1.5 \\
$\mathbf{5}$ & S16 & 93 & 95 & 2 \\
$\mathbf{6}$ & S 17 & 71.5 & 75 & 3.5 \\
$\mathbf{7}$ & S18 & 66.5 & 75 & 8.5 \\
$\mathbf{8}$ & S 19 & 69 & 58 & -11 \\
$\mathbf{9}$ & S 20 & 62 & 73 & 11 \\
$\mathbf{1 0}$ & S 21 & 90 & 75 & -15 \\
$\mathbf{1 1}$ & S 22 & 50 & 70 & 20 \\
Mean & & 72.55 & 73.36 & 0.82 \\
\hline
\end{tabular}

Secara

umum dengan membandingkan hasil pre test, kedua kelas memperlihatkan hasil yang tidak jauh berbeda. Pada kelas eksperimen dapat dilihat bahwa rata-rata beda antara pre test dan post test adalah 5.14. Data tersebut lebih tinggi secara signifikan dari kelas kontrol yang hanya 0.82 . Hal ini menunjukkan bahwa siswa pada kelas eksperimen lebih unggul dari kelas kontrol. Ada dua siswa dalam kelas eksperimen dan empat siswa dalam kelas kontrol yang memiliki nilai rendah pada post test. Dalam dua tabel di bawah ini akan diperlihatkan secara deskripsi statistik perhitungan dengan menggunakan SPSS kedua kelas.

Responden dalam penelitian ini lebih kecil sama dengan dari 50, maka normalitas data yang digunakan adalah Shapiro-Wilk. Data memiliki distribusi normal jika nilai $p$ lebih besar atau sama dengan 0.05. Dari tabel 4.7 diperoleh sig. untuk kelas eksperimen dan kelas kontrol $>0.005$. Hal tersebut mengindikasikan 
bahwa data pre test kedua kelas memiliki distribusi normal.

Berdasarkan tabel 4.8 dapat dilihat bahwa tidak ada perbedaan yang signifikan antara kedua kelas dalam hasil pre test. Hal tersebut mengindikasikan bahwa level siswa dalam kedua kelas setara secara umum. Informasi ini penting untuk menganalisis hasil post test, sebagai perbandingan kelas kontrol yang mendapat pengajaran konvensional dan kelas eksperimen yang mendapat pengajaran dengan menggunakan Microsoft Mathematics. Level pengetahuan siswa berdasarkan konten materi matematika dalam kelas eksperimen dan kelas kontrol dapat didefinisikan sebagai level yang baik jika berada pada nilai 72-74 (dari nilai maksimum 100).

Tabel 4.7 Normalitas Data Pre Test

\begin{tabular}{|l|r|r|r|r|r|r|}
\hline & \multicolumn{3}{|c|}{$\begin{array}{c}\text { Kolmogorov- } \\
\text { Smirnov }\end{array}$} & \multicolumn{3}{|c|}{} \\
& \multicolumn{2}{|c|}{ Shapiro-Wilk } \\
\cline { 2 - 7 } & Statistic & df & Sig. & Statistic & df & Sig. \\
\hline ExperimentalGroup & .209 & 11 & .197 & .919 & 11 & .311 \\
ControlGroup & .253 & 11 & .048 & .839 & 11 & .301 \\
\hline
\end{tabular}

a. Lilliefors Significance Correction

Tabel 4.8. Deskripsi Statistik Hasil Pre Test

\begin{tabular}{|c|c|c|c|c|}
\hline Group & $\mathbf{N}$ & Mean & $\begin{array}{l}\text { Std. } \\
\text { Deviation }\end{array}$ & $\begin{array}{l}\text { Std. } \\
\text { Error } \\
\text { of } \\
\text { Mean }\end{array}$ \\
\hline $\begin{array}{l}\text { Pre Test } \\
\text { 1. Experimental } \\
\text { Group } \\
\text { 2. } \text { Control } \\
\text { Group }\end{array}$ & $\begin{array}{l}11 \\
11\end{array}$ & $\begin{array}{l}74.3182 \\
72.5455\end{array}$ & $\begin{array}{l}12.87686 \\
12.50091\end{array}$ & $\begin{array}{l}3.88252 \\
3.76917\end{array}$ \\
\hline
\end{tabular}

Gambar 4.1 memperlihatkan representasi grafik berdasarkan frekuensi nilai yang diperoleh siswa pada masingmasing kelas.

\section{Graphical Representation of Pre Test}

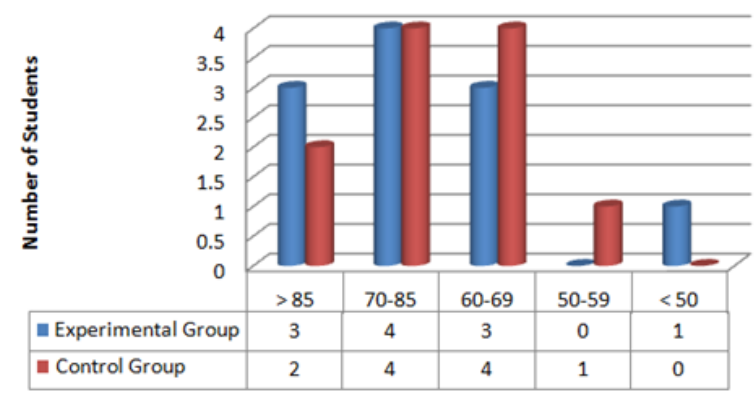

Gambar 4.1. Representasi Grafik Nilai

Pre Test Kelas Eksperimen dan Kelas Kontrol

Dari gambar di atas dapat dilihat bahwa frekuensi nilai untuk kedua kelas hampir mendekati setara, khususnya pada interval nilai 70-85. Tidak ada siswa dalam kelas eksperimen yang berada pada interval nilai 50-59, sebaliknya lebih banyak siswa yang mendapat nilai > 85. Selanjutnya di bawah ini disajikan deskripsi statistik untuk nilai post test baik dari kelas eksperimen dan kelas kontrol.

Tabel 4.9. Normalitas Data Post Test

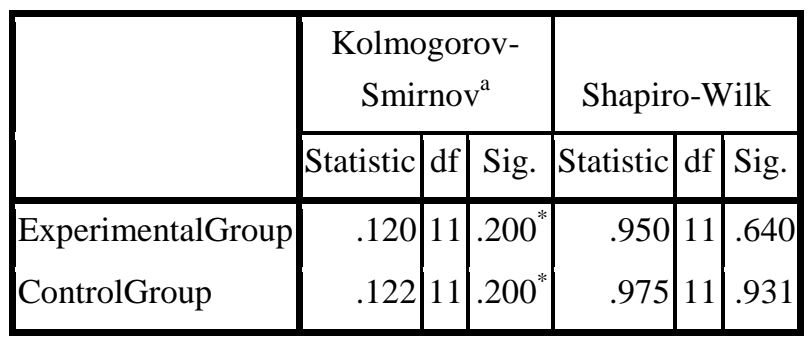

a. Lilliefors Significance Correction

*. This is a lower bound of the true significance.

Dari tabel 4.9 diperoleh sig. untuk kelas eksperimen dan kelas kontrol adalah > 0.05. Hal tersebut 
mengindikasikan bahwa data nilai post test memiliki distribusi normal.

Tabel 4.10 Deskripsi Statistik Hasil Pre Test

\begin{tabular}{|l|l|l|l|l|}
\hline Group & N & Mean & $\begin{array}{l}\text { Std. } \\
\text { Deviation }\end{array}$ & $\begin{array}{l}\text { Std. } \\
\text { Error } \\
\text { of } \\
\text { Mean }\end{array}$ \\
\hline $\begin{array}{l}\text { Post } \\
\text { Test } \\
\begin{array}{l}\text { 1. Exp } \\
\text { Group } \\
\text { 2.Control } \\
\text { Group }\end{array}\end{array}$ & 11 & 79.4545 & 10.57699 & 3.18908 \\
\hline
\end{tabular}

Pada tabel 4.10 dapat dijelaskan bahwa nilai rata-rata terbesar diperoleh kelas eksperimen dengan beda sebesar 6.09. Hal tersebut mendeskripsikan hasil yang signifikan untuk pembelajaran pada kelas eksperimen lebih baik dari kelas kontrol. Di bawah ini grafik yang menunjukkan hasil post test kedua kelas berdasarkan frekuensi nilai yang diperoleh siswa.

\section{Graphical Representation of Post Test}

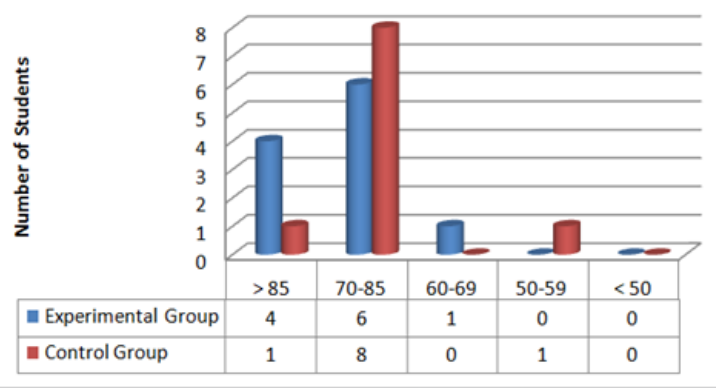

Gambar 4.2. Representasi Grafik Nilai

Pre Test Kelas Eksperimen dan Kelas Kontrol

Pada gambar 4.2 menggambarkan bahwa frekuensi nilai > 85 lebih banyak berada pada kelas eksperimen dan interval nilai 70-85 lebih banyak diperoleh pada kelas kontrol. Data tersebut jelas menentukan bahwa kinerja

Pengembangan ... (Laela Sagita) siswa dalam kelas eksperimen lebih baik di kelas kontrol.

\section{Sikap Siswa dan Kepercayaan Diri Dalam Matematika dan Komputer}

Setelah melakukan pembelajaran baik konvensional pada kelas kontrol atau berbantuan Microsoft Mathematics pada kelas eksperimen, subjek pada kedua kelas mengisi kuisioner 1 mengenai mathematics confidence attitudes dan kuisioner 2 mengenai computer confidence attitudes. Di bawah ini detil hasil perolehan pengisian kuisioner dari kelas eksperimen dan kelas kontrol.

Tabel 4.11 Nilai Siswa Kelas Eksperimen untuk Perolehan Kuisioner 1 dan 2

\begin{tabular}{ccc}
\hline $\begin{array}{c}\text { Students' } \\
\text { Code }\end{array}$ & $\begin{array}{c}\text { Mathematic } \\
\text { S } \\
\text { Confidence }\end{array}$ & $\begin{array}{c}\text { Computer } \\
\text { Confidence }\end{array}$ \\
S1 & 52 & 59 \\
S2 & 48 & 56 \\
S3 & 41 & 50 \\
S4 & 31 & 42 \\
S5 & 35 & 44 \\
S6 & 32 & 38 \\
S7 & 29 & 52 \\
S8 & 39 & 46 \\
S9 & 48 & 53 \\
S10 & 42 & 54 \\
S11 & 49 & 54 \\
Mean & $\mathbf{4 0 . 5 5}$ & $\mathbf{4 9 . 8 2}$ \\
\hline
\end{tabular}

Tabel 4.12 Nilai Siswa Kelas Kontrol untuk Perolehan Kuisioner 1 dan 2

\begin{tabular}{ccc}
\hline $\begin{array}{c}\text { Students' } \\
\text { Code }\end{array}$ & $\begin{array}{c}\text { Mathematic } \\
\text { S Confidence }\end{array}$ & $\begin{array}{c}\text { Computer } \\
\text { Confidence }\end{array}$ \\
\hline S12 & 37 & 35 \\
S13 & 46 & 49 \\
S14 & 26 & 60 \\
S15 & 42 & 45 \\
S16 & 40 & 57 \\
S17 & 42 & 47 \\
S18 & 48 & 54 \\
S19 & 46 & 45 \\
S20 & 50 & 47 \\
S21 & 46 & 60 \\
S22 & 47 & 51 \\
\hline
\end{tabular}




\begin{tabular}{lll}
\hline Mean & 42.73 & 45.83 \\
\hline
\end{tabular}

Tabel di bawah ini memperlihatkan hasil perhitungan reliabilitas Cronbach's Alpha untuk kelas eksperimen dan kelas kontrol. Dari tabel tersebut diperlihatkan bahwa nilai reliabilitas tinggi dan dapat diterima sebagai instrumen yang reliabel untuk tujuan penelitian ini.

Tabel 4.13 Koefisien Reliabilitas Cronbach's Alpha

\begin{tabular}{|l|l|l|}
\hline Method & Item & $\begin{array}{l}\text { Cronbach's } \\
\text { Alpha }\end{array}$ \\
\hline Experiment & Overall & .863 \\
Group & Mathematics & .836 \\
& Confident & \\
& Computer Confident & .909 \\
Control & Overall & .950 \\
Group & Mathematics & .810 \\
& Confident & \\
& Computer Confident & .728 \\
\hline
\end{tabular}

Gambar di bawah ini merupakan representasi grafik mengenai sikap siswa terhadap mathematics confidence. Berdasarkan grafik sebagian besar siswa pada kelas kontrol memiliki sikap yang baik berhubungan dengan kepercayaan diri terhadap matematika dan secara umum siswa pada kelas eksperimen memiliki sikap 'excellent'.

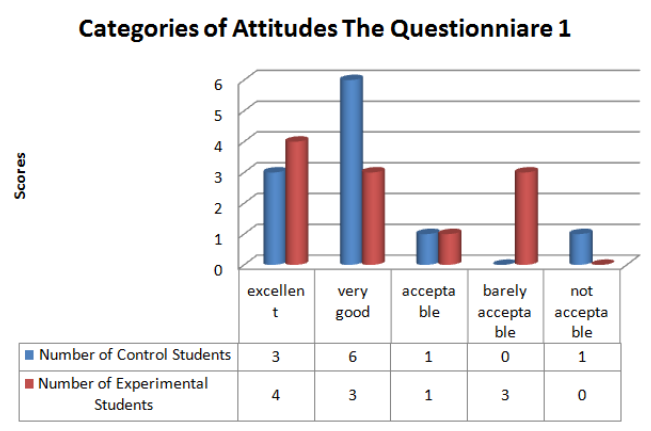

Gambar 4.3 Kategori Sikap Siswa

Terhadap mathematics confidence

Berkenaan dengan computer confidence, pada gambar 4.4 dapat diperlihatkan bahwa umumnya siswa pada kelas kontrol memiliki sikap baik dan sebagian siswa pada kelas eksperimen memiliki sikap 'excellent'.

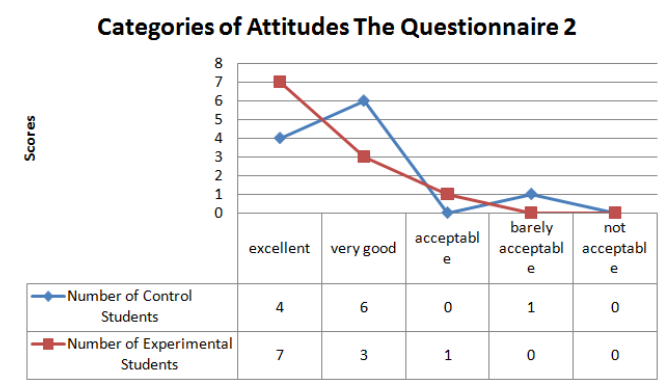

Gambar 4.4 Kategori Sikap Siswa

Terhadap computer confidence

\section{Sikap Siswa Terhadap Pembelajaran} dengan Microsoft Mathematics

Kelas eksperimen diberikan kuisioner tambahan mengenai sikap terhadap pembelajaran berbantuan Microsoft Mathematics. Pada tabel 4.14 diperlihatkan nilai setiap subjek pada kelas eksperimen dalam menjawab kuisioner 3. Nilai rata-rata adalah 42.36 dan sebagian besar subjek merespon positif dan memiliki sikap yang baik.

Tabel 4.14 Nilai Subjek Kelas

Eksperimen untuk Kuisioner 3

\begin{tabular}{cccc}
\hline $\begin{array}{c}\text { Students' } \\
\text { Code }\end{array}$ & Scores & $\begin{array}{c}\text { Students' } \\
\text { Code }\end{array}$ & Scores \\
S1 & 48 & S7 & 40 \\
S2 & 43 & S8 & 47 \\
S3 & 49 & S9 & 31 \\
S4 & 41 & S10 & 42 \\
S5 & 37 & S11 & 43 \\
S6 & 45 & Mean & $\mathbf{4 2 . 3 6}$ \\
\hline
\end{tabular}

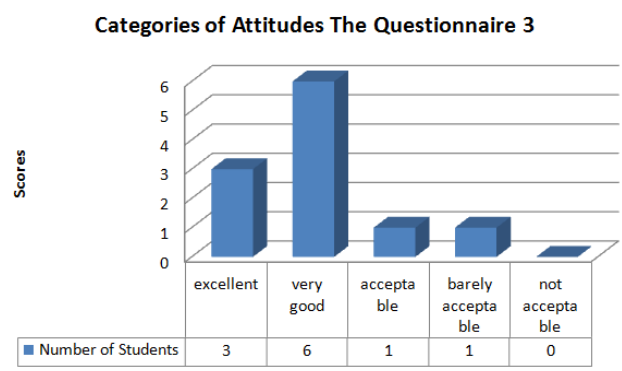


Gambar 4.5 Kategori Sikap Siswa

Terhadap Microsoft Mathematics

Dari gambar di atas dapat dideskripsikan bahwa sebagian besar siswa memiliki sikap baik berhubungan dengan penggunaan Microsoft Mathematics dalam pembelajaran Kalkulus. Membandingkan dengan yang lain, S9 memiliki nilai yang rendah dan dalam sikap berada pada kategori 'barely acceptable'. Dengan wawancara langsung pada subjek, dia menyetujui bahwa siswa akan kehilangan banyak waktu dalam belajar karena dia percaya ketika siswa belajar matematika menggunakan program komputer selama pembelajaran maka akan membutuhkan waktu yang banyak untuk mengatasi permasalahan teknis. Respon pesimis berbeda yang dating dari subjek lain yaitu bahwa matematika dengan menggunakan teknologi komputer hanya akan berhasil jika siswa memiliki akses ke komputer di rumah dan membutuhkan waktu tambahan untuk memahami matematika yang tanpa komputer pun sudah kompleks, rumit, dan cukup sulit. Komentar tersebut diungkapkan oleh S5 yang memiliki kompleksitas tidak hanya dalam matematika tetapi juga dalam menggunakan komputer.

Sebagian besar siswa menyadari pentingnya teknologi pendidikan (tabel 4.2 dan 4.3), untuk kepentingan tersebut maka opini siswa mengenai efek mengadopsi teknologi pendidikan dalam hal ini Microsoft Mathematics perlu ditambahkan.

Tabel 4.15 Efek Mengadopsi Microsoft Mathematics

\begin{tabular}{lccc}
\hline \multicolumn{1}{c}{ Efek } & Setuju & $\begin{array}{c}\text { \% } \\
\text { Tidak } \\
\text { Yakin }\end{array}$ & $\begin{array}{c}\text { Tidak } \\
\text { Setuju }\end{array}$ \\
& & 36.36 & 18.18 \\
Meningkatkan prestasi siswa (contoh: nilai) & 45.45 & 36.36 & 18.18 \\
Mendorong kolaborasi siswa & 45.45 & 36.36 & 18.18 \\
Mendorong perkembangan siswa dalam kemampuan komunikasi & 45.45 & 5.09 \\
$\begin{array}{l}\text { Memperkaya pembelajaran matematika siswa (contoh: belajar } \\
\text { dengan metode berbeda) }\end{array}$ & 54.55 & 36.36 & 9.09 \\
$\begin{array}{l}\text { Memotivasi siswa untuk lebih terlibat dalam kegiatan belajar di } \\
\text { kelas }\end{array}$ & 54.55 & 36.36 & 9.09 \\
\hline Meningkatkan pembelajaran siswa mengenai ide dan konsep & 72.73 & 18.18 & 9 \\
\hline
\end{tabular}

Proses wawancara ditambahkan untuk melengkapi data. Inti materi wawancara adalah mengenai efek mengadopsi Microsoft Mathematics dalam pembelajaran, khususnya belajar mengajar Kalkulus. Berdasarkan jawaban siswa dirangkum tiga keutaman penggunaan Microsoft Mathematics.

Tabel 4.16 Tiga Keutamaan Penggunaan Microsoft Mathematics Berdasarkan Wawancara

\begin{tabular}{|c|c|c|}
\hline Aspek Wawancara & Jawaban Siswa & Subjek \\
\hline \multirow[t]{3}{*}{$\begin{array}{l}\text { Bermanfaat dalam } \\
\text { belajar Kalkulus }\end{array}$} & $\begin{array}{l}\text { "sangat menarik menjawab soal Kalkulus dengan Microsoft } \\
\text { Mathematics, saya bisa membayangkan process penyelesaiannya } \\
\text { dan bisa menggambarkan secara visual" }\end{array}$ & S8 \\
\hline & $\begin{array}{l}\text { "Pemahaman saya terbantu dengan program ini, sehingga saya } \\
\text { dapat melihat proses penyelesaian masalah langkah demi langkah" }\end{array}$ & S3 \\
\hline & "Microsoft Mathematics adalah program yang menyenangkan dan & S1 \\
\hline
\end{tabular}




\begin{tabular}{|c|c|}
\hline & $\begin{array}{l}\text { menambah pengetahuan saya dalam penyelesaian masalah dalam } \\
\text { berbagai cara" }\end{array}$ \\
\hline \multirow[t]{2}{*}{ Mudah digunakan } & $\begin{array}{l}\text { "Program matematika ini mudah dijalankan terutama untuk S10 } \\
\text { menggambar grafik" }\end{array}$ \\
\hline & $\begin{array}{l}\text { "Perintah dalam program ini tidak sulit dimengerti dan saya bisa S4 } \\
\text { mengoperasikannya dengan mudah" }\end{array}$ \\
\hline $\begin{array}{l}\text { Membantu siswa } \\
\text { dalam }\end{array}$ & $\begin{array}{l}\text { "Microsoft Mathematics memfasilitasi pemahaman saya tentang S2 } \\
\text { konsep materi lebih nyata dari penjelasan dosen" }\end{array}$ \\
\hline $\begin{array}{l}\text { mengkonkretisasi } \\
\text { materi }\end{array}$ & $\begin{array}{l}\text { "Program ini membuat materi Kalkulus yang dijelaskan dosen S6 } \\
\text { semakin jelas" }\end{array}$ \\
\hline
\end{tabular}

Microsoft Math

Memperkaya

Pembelajaran dan Meningkatkan

\section{Motivasi Siswa}

Kalkulus merupakan mata kuliah dasar yang dipelajari oleh siswa Universitas Serang Raya di tahun pertama. Belajar Kalkulus berkaitan dengan kompleksitas dan kesulitan. Menurut pengalaman penulis dalam kuliah Kalkulus pada siswa tahun pertama di jurusan Sistem Komputer, Universitas Serang Raya, diketahui bahwa kelemahan sebagian besar siswa adalah dalam memahami materi Kalkulus yang abstrak dan hanya mampu melakukan perhitungan sederhana. Pembelajaran yang difasilitasi oleh teknologi dapat dipergunakan untuk membantu siswa dalam mepelajari Kalkulus.

Microsoft Mathematics adalah salah satu peranngkat lunak teknologi pendidikan yang dibuat oleh Microsoft Corporation yang dapat membantu siswa memvisualisasikan masalah. Menurut Microsoft Mathematics (2010) ada tiga keuntungan menggunakan Microsoft Mathematics dalam belajar matematika yaitu (1) freeware with structured menu, (2) some of the menu provide solution, dan (3) helpful visualization [27].
Menggunakan Microsoft Mathematics diharapkan dapat membantu siswa dalam memahami konsep-konsep Kalkulus dan memperkaya pembelajaran matematika siswa.

Dari pengumpulan data mengenai efek mengadopsi Microsoft Mathematics diperoleh 54.55\% siswa setuju bahwa Microsoft Mathematics dapat memperkaya wawasan siswa dalam belajar matematika. Hal ini seperti yang ditegaskan Chin (2004) bahwa, "utilizing technology not only builds students' confidence with using technology, but also enhances learning and keeps students engaged" [28].

Menurut data yang ditunjukkan pada tabel 4.15 diperoleh $54.55 \%$ siswa setuju bahwa Microsoft Mathematics dapat memotivasi siswa untuk lebih terlibat dalam kegiatan pembelajaran di kelas. Siswa terbantu oleh program ini karena memberikan kemudahan dalam pengoperasian dan komputasi matematika. Menulis, menghitung, manipulasi persamaan matematika, visualisasi grafis 2D-3D, dan animasi dapat diarahkan dengan mudah dan menunjukkan proses pemecahan masalah langkah demi langkah. 


\section{Kesimpulan}

Dari penelitian ini bersama dengan penelitian sebelumnya tentang penggunaan komputer untuk tujuan pendidikan menunjukkan bahwa penerapan program komputer di kelas sangat penting untuk meningkatkan pemahaman dan membantu siswa dalam pembelajaran. Visualisasi interaktif yang merupakan cabang dari visualisasi grafis dalam ilmu komputer adalah komponen penting yang ditawarkan Microsoft Mathematics. Hal tersebut memudahkan siswa untuk lebih memahami konten matematika dan melibatkan siswa dalam mempelajari bagaimana berinteraksi dengan komputer untuk meningkatkan representasi yang tidak diperoleh dengan pengajaran konvensional. Seperti hasil yang ditunjukkan oleh siswa pada kelas eksperimen dalam post test dibandingkan dengan presntasi siswa pada kelas kontrol.

Temuan dari laporan penelitian ini secara umum pengaruh positif dari teknologi pendidikan, dalam hal ini menerapkan Microsoft Mathematics dalam memperkaya proses belajar siswa dan meningkatkan motivasi siswa untuk lebih terlibat dalam kegiatan pembelajaran di kelas. Interaktivitas dan visualisasi adalah dua komponen penting yang dimiliki program ini. Dua komponen tersebut membantu siswa untuk lebih memahami isi materi matematika. Seperti yang telah diperlihatkan oleh respon siswa melalui pengisian kuisioner dan wawancara yang terkait dengan Microsoft Mathematics, mereka menunjukkan minat dalam menggunakan program ini untuk mendukung eksplorasi siswa dalam belajar matematika. Secara keseluruhan dampak positif proses belajar mengajar dengan menggunakan teknologi dalam pendidikan telah dibuktikan oleh banyak studi (Rutz et al., 2003, Hennessy et al., 2010, Brown J., 2011) [29] [30] [31]. Untuk memiliki pemahaman yang lengkap dari pengaruh Microsoft Mathematics, penellitian perlu memperluas langkah hasil di domain kognitif dan afektif.

\section{Pustaka}

[1]Lawless, K. A., \& Pellegrino, J. W, 2007 , Professional Development in Integrating Technology into Teaching and Learning: Known's, Unknowns, and Ways to Pursue Better Questions and Answers, Review of Educational Research, Volume 77, No. 4, pp. 575-614

[2]Surjono, Herman D, 2010, Pemanfaatan Teknologi Informasi dan Komunikasi dalam Peningkatan Kualitas Pembelajaran, Makalah disajikan dalam seminar MGMP Terpadu SMP/MTs Kota Magelang.

[3]Kelly, D. \& Tangney, B, 2006, Adapting to Intelligence Profile in an Adaptive Educational System, Journal Interacting with Computers, Volume 18, No. 3, pp. 385-409 
[4]Curri, Elira, 2012, Using Computer Technology in Teaching and Learning Mathematics in an Albanian Upper Secondary School, University of Agder: Kristiansand.

[5]National Council of Teachers of Mathematics, 2000, Principles and standards for school mathematics. Reston, VA: Author.

[6]Bransford, J. D., Brown, A. L., Cocking, R. R., Donovan, M. S., \& Pellegrino, J. W. (Eds.), 2000, How people learn: Brain, mind, experience, and school (Expanded ed.), Washington, DC: National Academy Press, Retrieved from:http://books.nap. edu/openook.php?record_id=985 3\&page [Diunduh 01 Desember 2013]

[7]henning [14] Christy [15] Duval [16] Wheatley \& Brown [18] Chiappini \& Bottino cited in Curri, Elira, 2012, Using Computer Technology in Teaching and Learning Mathematics in an Albanian Upper Secondary School, University of Agder: Kristiansand.

[8] [9] [17]Time in Ashburn, E. A., \& Floden, R. E., 2006, Meaningful learning using technology: What educators need to know and do, New York: Teachers College Press.
[10]Churchill, D., 2005, Learning objects: an interactive representation and a mediating tool in a learning activity, Educational Media International, Volume 42, No. 4, pp. 333-349, Retrieved from:http://www.edit lib.org/p/97869 [Diunduh 01 Desember 2013]

[11] [13]Mayer, R., 2001, Multimedia Learning, New York: Cambridge University Press.

[12]Paivio, A., 2006, Dual coding theory and education: Pathways to Literacy Achievement for High Poverty Children. University of Michigan School of Education, Retrieved from:http://www.umi ch.edu/ rdytolrn/pathwaysconfe rence/presentations/paivio.pdf [Diunduh 01 Desember 2013]

[13]Marjuni, A, 2007, Media Pembelajaran Matematika dengan Maplet, Yogyakarta: Graha Ilmu.

[19]Byers, P., 2010, Investigating Trigonometric Representations in The Transition to College Mathematics, College Quarterly, Volume 13, No. 2, Retrieved from:http://www.collegequarterl y.ca/2010-vol13-num02-

spring/byers.html [Diunduh 01 Desember 2013]

[20]Beynon, Nehaniv, \& Dautenhahn; Jonassen \& Carr, Lajoie; Sedig \& Liang, cited in Liang, H.-N., \& Sedig, K, 2010, Can interactive visualization tools 
engage and support preuniversity students in exploring non-trivial mathematical concepts?, Elsevier Science Press: Computers \& Education, Volume 54, No. 4, pp. 972-991

[21]Hogstad, P. H. \& Brekke, M., 2010, New teaching Methods - Using Computer Technology in Physics, Mathematics and Computer Science, International Journal of Digital Society (IJDS), Volume 1, No. 1, pp. 1724

[22]Fogarty, G., Cretchley, P., Harman, C., Ellerton, N., \& Konki, N., 2001, Validation of A Questionnaire to Measure Mathematics Confidence, Computer Confidence and Attitudes Towards Technology For Learning Mathematics, Mathematics Education Research Journal, Volume 13, No. 2, pp. 154-159

[23]Bryman, A., 2008, Social research methods, Oxford University Press.

[24]Wijaya, 2000, Analisis Statistik dengan Program SPSS 10.00, Bandung : CV Alfabeta.

[25]MacDonald, R. J., 2008, Professional Development for information communication technology integration: Identifying and supporting a community of practice through design-based research, Journal of Research on Technology in
Education, Volume 40, No. 4, pp. $429-445$

[26]Wilson, S. J., 2008, Dynamic web tools for trigonometry, Innovations in Math Technology, Paper 2.

[27]Microsoft Mathematics, Your Students' Interest will Multiply with Microsoft $®$ Mathematics, Microsoft Corporation: US, 2010.

[28]P. Chin, Using C \& IT to Support Teaching, RoutledgeFalmer: New York, 2004.

[29]E. Rutz, R. Eckart, J. Wade, Maltbie, "Student Performance and Acceptance of Instructional Teaching: Comparing Technology Enhanced and Traditional Instruction for A Course in STATICS", in Journal of Engineering Educational, Vol. 92, Issue 2, Virginia, 2003.

[30]S. Hennessy, B. Onguko, D. Harrison, E.K. Ang'ondi, S. Namalefe, A. Naseem, L. Wamakote, Developing the Use of Information and Communication Technology to Enhance Teaching and Learning in East African Schools: Review of the Literature, University of Cambridge: UK, 2010.

[31]J. M. Brown, Does The Use of Technology in The Classroom Increase Students' Overall Academic Performance?, Gonzaga University: US, 2011. 